\title{
CHARITABLE GIVING AND TAX LEGISLATION IN THE REAGAN ERA
}

\author{
Charles T. Clotfelter*
}

I

\section{INTRODUCTION}

The nonprofit sector-a multi-billion dollar amalgam that includes churches, hospitals, colleges and universities, symphonies, museums, and social welfare agencies-receives a sizable portion of its support in the form of charitable contributions. ${ }^{1}$ In 1983 , individual donors contributed almost $\$ 54$ billion to charitable nonprofit organizations, as shown in Table 1. Charitable bequests and corporate contributions added another $\$ 7$ billion. Although few

TABLE 1

Charitable Giving in 1983 by Source ${ }^{a}$

\begin{tabular}{lcr}
\hline \hline Source & $\begin{array}{c}\text { Amount } \\
\text { (billions) }\end{array}$ & Percent \\
\hline Individuals & $\$ 53.9$ & 88 \\
Estates & 4.5 & 7 \\
Corporations & 3.1 & $\frac{5}{100}$ \\
Total & $\$ 61.5$ &
\end{tabular}

aAmerican Assoc. of Fund-Raising Counsel, InC., Grving USA 42 (1984).

would claim that taxes are the most important determinant of such contributions, it is now widely accepted that taxes are one important influence in determining the amount of such giving. ${ }^{2}$ The federal income and estate tax laws allow deductions for charitable gifts. The income tax provides to those who itemize their deductions a charitable deduction covering gifts of cash and other property to qualifying charitable nonprofit organizations. ${ }^{3}$ Corporations are allowed to deduct charitable gifts up to $10 \%$ of net income. ${ }^{4}$ Under the estate tax, charitable bequests are allowed to reduce the taxable

Copyright $\odot 1985$ by Law and Contemporary Problems

- Professor of Public Policy Studies and Economics, Duke University. The author is grateful to Christopher Marselli for programming assistance, to Pasty Terrell for manuscript preparation, and to Independent Sector and the Association of American Universities for research support. The views expressed here are the author's and do not necessarily reflect those of any organization.

1. C. Clotfelter, Federal Tax Policy and Chartable Giving ch. 1 (1985).

2. See, e.g., Clotfelter \& Steuerle, Charitable Contributions, in How Taxes Afrect Economic Behavior 403 (H. Aaron \& J. Pechman eds. 1981).

3. I.R.C. \& 170 (Lawyers Co-op. 1974 \& Supp. 1985).

4. Id. \& $170(\mathrm{~b})(2)$. 
estate without limit. ${ }^{5}$ A sizable amount of econometric evidence has been amassed to suggest that these deduction provisions, as well as the marginal tax rates for each income bracket, influence giving to charitable organizations by individuals, corporations, and estates. ${ }^{6}$ It is not surprising, therefore, to discover that charitable organizations view tax reform with some trepidation, fearing that changes in the tax system may reduce charitable giving. An analysis of tax legislation in the Reagan Administration suggests that the effects of various reforms, either enacted or proposed, may vary considerably, depending on which groups of taxpayers are most affected by the changes.

In recent years, tax legislation has been an area of considerable activity, with at least one major tax bill being passed every other year. The first major tax bill of the Reagan Administration, the Economic Recovery Tax Act of 1981 (ERTA), ${ }^{7}$ contained several provisions that are likely to affect charitable contributions directly or indirectly. The 1982 tax act, ${ }^{8}$ in contrast, had only a minor effect on charitable giving. It would be quite incomplete to limit the discussion of tax legislation in the "Reagan era" to those two acts, however. With the encouragement and participation of the President and his supporters, a number of important tax alternatives have been actively discussed from the first days of the Administration, including "flat-rate" income taxes, an expenditure tax, and a value-added tax. ${ }^{9}$ Flat-rate income taxes would literally impose a constant rate of taxation on all taxable income. More generally, the generic category of flat-rate taxes has been applied to a number of proposals that broaden the income tax base and cut the top tax rates, whether the rate structure is actually flat or not. For example, the Treasury Department unveiled a detailed tax plan in November 1984 embodying many features of other comprehensive income tax proposals. In contrast, an expenditure tax would exempt savings from taxation but otherwise would look quite similar to the current income tax. A value-added tax would be levied on firms at each stage of production. ${ }^{10}$ Any full assessment of the impact of "Reagan era" tax legislation on charitable giving should account for tax proposals such as these as well as actual legislation during the Reagan Administration.

This article examines the effects of actual and potential tax legislation on charitable contributions. Most attention is devoted to the impact on contributions by individuals because of the overwhelming importance of such gifts, but the effects on corporate and bequest giving are also noted. Section

5. Id. $§ 2055$ (a) (Lawyers Co-op. $1978 \&$ Supp. 1985).

6. See, e.g., Feldstein \& Taylor, The Income Tax and Charitable Contributions, 44 Econometrica 1201 (1976).

7. Pub. L. No. 97-34, 95 Stat. 172.

8. Tax Equity and Fiscal Responsibility Act of 1982 (TEFRA), Pub. L. No. 97-248, 96 Stat. 324.

9. E.g., S. 557, 98th Cong., 1st Sess., 129 Conc. Rec. S1507 (daily ed. Feb. 23, 1983) (HallRubushka, DeConcini) (flat tax); Blueprints for Basic Tax Reform (expenditure); 3 U.S. DEP'T OF THE Treas., Report to the President: Tax Reform for Fairness, Simplicity, and Economic Growth (1984).

10. See R. Musgrave \& P. Musgrave, Public Finance in Theory and Practice 458-63 (3d ed. 1980 ), for a discussion of value-added taxes. 
II discusses the relationship between tax structure and charitable giving. The effect of taxes on the net income of potential donors and the "tax-price" of their contributions is emphasized. In addition, Section II outlines the tax effects on the distribution of giving by type of organization. Section III discusses the provisions of ERTA and their effect on charitable giving by individuals. Section IV discusses the effects of ERTA on bequest and corporate giving. Section V examines the likely effect of tax reform proposals, such as a flat-rate income tax, an expenditure tax, and a value-added tax on the level and distribution of individual contributions.

\section{II}

\section{Taxes and Charitable Giving}

In order to assess the likely effects of tax legislation on charitable giving, it is necessary to turn to empirical research on giving behavior. It is especially important to examine the effect of taxes on disposable income and the net cost of contributions. It is also useful to assess the effect of taxes on the distribution of gifts by type of organization. Most of the section is devoted to considering contributions by individuals. Giving from estates and corporations is considered at the end of the section.

\section{A. Price and Income Effects}

Charitable behavior differs from ordinary consumer behavior in several obvious ways. Values, commitment, duty, and sympathy may play deciding roles in motivating charitable donations and volunteer behavior. Like ordinary consumer behavior, however, charitable giving is also affected by the capacity to give and the relative net cost of contributions. Capacity to make contributions may be measured by disposable income, that is, income after taxes. If charitable giving is a "normal" good, for which the demand increases as disposable income increases, an increase in tax liability would be expected to cause a decline in contributions. A tax cut, on the other hand, would stimulate giving.

Taxes also affect giving by influencing the net cost per dollar of contributions, and this effect is comparable to the effect of a commodity's price on its demand. If there were not a deduction for charitable giving, the gift of one dollar to a charitable organization would reduce the amount of other consumption possible by one dollar. If, on the other hand, contributions are subject to an income tax deduction, donations have the effect of reducing tax liability. Thus, the reduction in other consumption resulting from a one dollar gift is not a full dollar. For a person subject to a $25 \%$ marginal tax rate, for example, an increase in deductible contributions of one dollar would result in a reduction of $\$ .25$ in tax liability. Thus, the net cost of the gift would be only $\$ .75$ per dollar given. In the presence of a deduction for charitable giving, the net cost, the "price," of giving falls as the marginal tax rate rises. To illustrate how this price varies among actual taxpayers, Table 2 presents information on income, tax rates, and the net cost 
of contributions for taxpayers who itemized their deductions in 1982. For taxpayers at these average incomes, the marginal tax rate in 1982 varied from zero to $50 \%$. For taxpayers in the $50 \%$ rate bracket, contributions had a net

\section{TABLE 2}

Average Income and Contributions, Tax Rate and Net Cost of DONATIONS For TaXPayers WITH ITEMIZed Deductions, $1982^{a}$

\begin{tabular}{|c|c|c|c|c|}
\hline Income Class & $\begin{array}{l}\text { Average } \\
\text { Income }\end{array}$ & $\begin{array}{l}\text { Marginal } \\
\text { Tax Rate } \\
\text { (percent) }\end{array}$ & $\begin{array}{c}\text { Average } \\
\text { Contributions }\end{array}$ & $\begin{array}{c}\text { Net Cost Per } \\
\text { Dollar of Cash } \\
\text { Donations } \\
\text { (Tax-Price) } \\
\end{array}$ \\
\hline $\begin{array}{l}\text { Under } \$ 5,000 \\
\$ 5,000-10,000 \\
\$ 10,000-15,000 \\
\$ 15,000-20,000 \\
\$ 20,000-25,000 \\
\$ 25,000-30,000 \\
\$ 30,000-40,000 \\
\$ 40,000-50,000 \\
\$ 50,000-75,000 \\
\$ 75,000-100,000 \\
\$ 100,000-200,000 \\
\$ 200,000-500,000 \\
\$ 500,000-1,000,000 \\
\$ 1,000,000 \text { and over }\end{array}$ & $\begin{array}{r}\$ 2,565 \\
7,399 \\
12,403 \\
17,335 \\
22,482 \\
27,489 \\
34,473 \\
44,315 \\
58,653 \\
85,051 \\
131,625 \\
285,028 \\
667,500 \\
2,239,705\end{array}$ & $\begin{array}{r}0 \\
14 \\
16 \\
19 \\
22 \\
25 \\
33 \\
39 \\
44 \\
49 \\
50 \\
50 \\
50 \\
50\end{array}$ & $\begin{array}{r}192 \\
516 \\
583 \\
616 \\
646 \\
685 \\
813 \\
1,110 \\
1,511 \\
2,457 \\
4,531 \\
12,071 \\
33,807 \\
146,545\end{array}$ & $\begin{array}{r}\$ 1.00 \\
.86 \\
.84 \\
.81 \\
.78 \\
.75 \\
.67 \\
.61 \\
.56 \\
.51 \\
.50 \\
.50 \\
.50 \\
.50\end{array}$ \\
\hline
\end{tabular}

a Calculated from data in Epstein, Preliminary Income and Tax Statistics for 1982 Individual Income Tax Returns, 3 Stats. Income Bull., Winter 1983-84, at 11, 19, Table 1.

cost of only $\$ .50$ per dollar. Taxpayers who are not subject to tax, or who do not itemize their deductions, face a net cost of a full dollar. "

Table 2 makes clear that contributions by itemizing taxpayers rise with income and fall with the tax-defined price. Since income and net cost move in opposite directions, it is impossible to determine on the basis of data such as these to what extent the increase in giving as one moves up the income scale is due to increasing income and to what extent it is due to a falling net cost per dollar giving.

In order to disentangle the effects of income and net cost, it is necessary to hold one factor constant and examine the other. For example, one may examine the giving behavior of taxpayers who itemize their deductions compared to taxpayers who do not at given levels of income, as shown in

11. One important complication in the calculation of tax price is giving in the form of appreciated assets, which would otherwise be subject to long-term capital gains treatment. See Feldstein \& Taylor, supra note 6, at 1202-04, 1205-06, for a discussion of how this consideration may be taken into account in calculating tax price. This article ignores gifts of appreciated assets, but the simulations presented infra account for the proportion of gifts made in noncash form and assume a gain-to-basis ratio for contributed assets for $50 \%$. See C. Clotrelter, supra note 1 , at ch. 2, for futher discussion. 
TABLE 3

Average Giving by Income and Itemization Status, 1973a

\begin{tabular}{lcc}
\hline \hline Income & Itemized & Did Not Itemize \\
\hline Less than $\$ 4,000$ & $\$ 119^{*}$ & $\$ 69$ \\
$\$ 4,000-7,999$ & 215 & 89 \\
$\$ 8,000-9,999$ & 314 & 117 \\
$\$ 10,000-14,999$ & 407 & 201 \\
$\$ 15,000-19,999$ & 600 & 329 \\
$\$ 20,000-29,999$ & 800 & 354 \\
$\$ 30,000-49,999$ & 1,564 & $171^{*}$ \\
$\$ 50,000-99,999$ & 5,679 & $3,190^{*}$ \\
$\$ 100,000-199,999$ & 17,106 & $816^{*}$ \\
$\$ 200,000-499,999$ & 39,763 & $8,892^{*}$ \\
$\$ 500,000$ or more & 71,316 & $5,000^{*}$ \\
All & 775 & $\$ 140$ \\
\hline
\end{tabular}

a Morgan, Dye \& Hybels, Results from Two National Surveys of Philanthropic Activity, in I ReSEARCH PAPERS 157, 193, Table 24 (Commission on Private Philanthropy \& Public Needs, U.S. Dept. of Treasury 1977).

*Based on fewer than 25 observations.

Table 3. The table shows that, at each income level, taxpayers who itemize their deductions give more than those who do not itemize. Such a difference would be consistent with the hypothesis that the price reduction created by a deduction has an effect independent of income. This is not a definitive test, however. Taxpayers at a given income who itemize their deductions may differ systematically from those who do not. In order to examine the effect of net cost on the giving of taxpayers who itemize, it is necessary to turn to econometric techniques to separate the effects of income and net cost. Such econometric studies can use information on differences in giving over a large number of taxpayers to infer the independent effects of income, net cost, and other factors, such as age and family composition.

Such econometric studies have been performed for a wide variety of data sources, some including nonitemizers and some not. ${ }^{12}$ The strong consensus arising from these studies is that net income and price have separate effects on giving. ${ }^{13}$ Although there is variability in specific parameter estimates, an income elasticity of about 0.7 and a price elasticity of about -1.3 are quite representative of a broad range of econometric findings. ${ }^{14}$ An income elasticity of 0.7 implies that a $10 \%$ increase in net income would, other things equal, be associated with an increase in giving of about $7 \%$. A price elasticity of -1.3 would imply an increase in giving of about $13 \%$ in response to a drop in the tax price of $10 \%$, say from 0.6 to 0.54 .

This empirical work has rather specific implications for the effect of tax legislation on charitable giving. Any legislation that significantly changes tax

12. For a summary of some of these studies, see Clotfelter \& Steuerle, supra note 2, at 407-22.

13. See id.

14. For a review of econometric estimates of such elasticities, see Clotfelter \& Steuerle, supra note 2. 
prices or after-tax incomes will be expected to influence the level of giving. The legislation likely to have the most profound effect on contributions would be any elimination or major modification of the charitable deduction itself. Feldstein and Taylor estimated that the elimination of the charitable deduction would cause contributions by itemizers to fall by $25 \% .^{15} \mathrm{By}$ the same token, flat-rate tax schemes $^{16}$ that would eliminate the charitable deduction could be expected to have similar effects. Although such legislative changes would affect giving to some extent through effects on net income, their dominant impact would be in raising the tax price of making contributions. Less obviously, tax schemes that bring about a significant reduction in tax rates could have a marked effect on tax-defined prices for those who itemize and could bring about a reduction in giving. It is not necessary to experience anything as dramatic as a new tax bill in order to observe changes in prices for giving, however. Simply the effect of inflation on effective tax rates, through the process of "bracket creep," will affect the prices of taxpayers who move to different tax brackets. Similarly, inflation tends to make it desirable for some taxpayers to begin itemizing their deductions when previously they did not, as their expenditures exceed the threshold level for itemizing. Thus, the presence or absence of indexation of tax brackets will also be expected to affect charitable giving through the influence of inflation on effective tax rates. Actual and proposed tax legislation must therefore be examined for both intended and unintended effects on charitable giving.

\section{B. Distribution of Giving by Type of Organization}

Tax legislation, as well as inflation-induced bracket creep, will also be expected to affect the distribution of tax liabilities among taxpayers. If the aggregate total of income taxes increases or decreases, aggregate net income will change and so will contributions. It is more likely, however, that tax revenues for any actual or proposed legislation will be kept approximately constant. It is the distribution of these liabilities across taxpayers in different income brackets that is most likely to change. ${ }^{17}$ Because net income has a positive effect on contributions, taxpayers who enjoy tax cuts will tend to give more, and vice versa. Modifications in tax schedules may also change the distribution of prices among taxpayers, resulting in other changes in giving that would vary by income. For this reason, it is important to determine how the giving patterns of taxpayers vary across the income scale. Table 4 presents a percentage distribution of charitable gifts by households at different income levels, based on a survey taken in 1973. The table indicates,

15. Feldstein \& Taylor, supra note 6 , at $1206,1217-18$.

16. E.g., H.R. 542, 98th Cong., lst Sess., 129 Cong. Rec. H93 (daily ed. Jan. 6, 1983) (Crane); S. 557, 98th Cong., Ist Sess., 129 Cong. Rec. S1507 (daily ed. Feb. 23, 1983) (Hall-Rubushka, DeConcini).

17. In order to raise the same revenue that the current income tax raises, a flat-rate tax, even with an exemption, would tend to reduce tax liabilities at the upper income levels and increase them elsewhere. 
TABLE 4

Percentage of Contributions * to Type of Organization by INCOME, 1973a

\begin{tabular}{cccccccccc}
\hline \hline Income & Religion & \multicolumn{2}{c}{ Education } & $\begin{array}{c}\text { Combined } \\
\text { Appeals }\end{array}$ & $\begin{array}{c}\text { Medical/ } \\
\text { Health }\end{array}$ & Culture & $\begin{array}{c}\text { Other } \\
\text { Major }\end{array}$ & $\begin{array}{c}\text { Not } \\
\text { Identified } \dagger\end{array}$ & Total \\
\hline $\begin{array}{c}\$ 0-9,999 \\
\$ 10,000-\end{array}$ & $59 \%$ & $1 \%$ & $0 \%$ & $2 \%$ & $3 \%$ & $0 \%$ & $2 \%$ & $33 \%$ & $100 \%$ \\
$\begin{array}{c}19,999 \\
\$ 20,000-\end{array}$ & 67 & 1 & 0 & 3 & 3 & 0 & 4 & 22 & 100 \\
$\begin{array}{c}29,999 \\
\$ 30,000-\end{array}$ & 59 & 2 & 1 & 5 & 4 & 0 & 10 & 19 & 100 \\
49,999 & 42 & 5 & 7 & 6 & 3 & 3 & 6 & 28 & 100 \\
$\begin{array}{c}\$ 50,000- \\
99,999\end{array}$ & 16 & 9 & 1 & 10 & 11 & 4 & 19 & 30 & 100 \\
$\begin{array}{c}\$ 100,000- \\
199,999\end{array}$ & 10 & 14 & 5 & 9 & 10 & 5 & 6 & 41 & 100 \\
$\begin{array}{c}\$ 200,000- \\
499,999\end{array}$ & 8 & 27 & 6 & 10 & 11 & 6 & 8 & 24 & 100 \\
$\begin{array}{c}\$ 500,000- \\
\text { or more }\end{array}$ & 9 & 24 & 3 & 6 & 6 & 9 & 16 & 27 & 100 \\
\begin{tabular}{c} 
Total \\
\hline
\end{tabular} & 46 & 5 & 2 & 6 & 5 & 2 & 8 & 26 & 100 \\
\hline
\end{tabular}

* Percentages represent total gifts to donee by income class.

a Morgan,.Dye \& Hybels, Results from Two National Surveys of Philanthropic Activity, in I RESEARCH PAPERS 157, 208, Table 38 (Commission on Private Philanthropy \& Public Needs, U.S. Dept. of Treasury 1977).

†Information regarding donees was obtained only for the four major gifts of each donor; therefore additional giving could not be allocated to donee categories.

for example, that households with incomes between $\$ 20,000$ and $\$ 30,000$ in 1973 gave almost $60 \%$ of their contributions to religious organizations, $5 \%$ to combined appeals, and about $2 \%$ to colleges and universities. By contrast, taxpayers in the highest income group directed less than $10 \%$ of their gifts to religious organizations, about the same percentage to combined appeals, and almost a quarter of their gifts to colleges and universities. Because of differences in giving propensities such as these, the distributional consequences of tax legislation can have important ramifications for certain segments of the nonprofit sector.

\section{Corporations and Estates}

Qualitatively similar effects of taxation have been observed for corporate contributions and charitable bequests. The price effect for corporate giving appears to be considerably smaller than that for individual contributions, although its effect is still significant. After-tax net income appears to be an important determinant for such giving. ${ }^{18}$ The econometric evidence regarding charitable bequests is less certain, although it appears that the price effect for bequest giving is at least as large as that for individual

18. See C. Clotfelter, supra note 1 , at ch. 5 , for a review of this econometric research. 
contributions. ${ }^{19}$ The estate tax also affects bequests by affecting the size of the net estate. Although these sources of contributions are small relative to individual giving, it is nevertheless useful to consider tax effects in these areas as well.

\section{III}

\section{Economic Recovery Tax Act of 1981: Individual Giving}

In considering the effect of ERTA on charitable giving, it is important to focus on three principal provisions, only one of which specifically relates to charitable contributions. The act takes an important step in the treatment of contributions by separating the charitable deduction from other itemized deductions. Since 1982, even those taxpayers not choosing to itemize their deductions have been able to deduct at least some portion of their contributions in calculating taxable income. ${ }^{20}$ This "above-the-line" deduction has been introduced gradually. In 1982 and 1983, the deduction was worth $25 \%$ of the first $\$ 100$ of giving; in 1984 the limit was raised to $\$ 300$. In $1985,50 \%$ of gifts by nonitemizers are deductible without limit, and in 1986, all contributions by nonitemizers are to be deductible. A sunset provision provides that this special deduction will lapse in 1987 if not acted upon again before that time. ${ }^{21}$

The second major provision of the 1981 tax act relevant to the consideration of charitable donations is the general rate reduction. Although nominal tax brackets were left unchanged through 1984, tax rates were reduced for all of these brackets. ${ }^{22}$ The most important reductions occurred at the top tax brackets: tax rates were cut off at 50\%, beginning in $1982 .{ }^{23}$ This means that the top tax rate fell from $70 \%$ to $50 \%$ in that year. In lower tax brackets, there was a $23 \%$ proportional reduction in rates over three years. ${ }^{24}$ The third provision likely to affect charitable giving is the scheduled indexation of tax brackets beginning in 1985.25 After that date, the indexation will prevent purely inflation-induced increases in tax rates, thus preventing inflationary reductions in the price of giving.

It is possible to identify four main effects of the 1981 tax act on giving by individuals. Perhaps the clearest effect is the reduction in marginal tax rates for the highest income groups. For a taxpayer in the previous $70 \%$ bracket making a cash contribution, the price of giving increased by more than $60 \%$ as a result of the lower tax rates (from $\$ .30$ to $\$ .50$ per dollar). Although this overstates the actual percentage increase in price for many high income

19. See C. Clotfelter, supra note 1 , at ch. 6 .

20. I.R.C. \& 170(i) (Lawyers Co-op. Supp. 1985).

21. Id. \$ $170(\mathrm{i})(4)$.

22. Id. \& 1(a)-(d) (Lawyers Co-op. 1984).

23. Id.

24. Id.

25. Id. \&1(f). 
taxpayers subject to special tax provisions, ${ }^{26}$ the act had a large impact on the net cost of making contributions by individuals in upper income groups. If taxpayers in these income groups are as sensitive to the tax-defined price of giving as econometric models suggest, one would expect to observe large declines in contributions at these income levels. Second, the effects of the tax rate deductions at other income levels were offset in part or in whole by the failure to change nominal tax brackets before 1985. At the same time that tax rates were being cut, taxpayers were being bumped into higher tax brackets because of inflation. ${ }^{27}$ Whether the marginal tax rate rose or fell for given taxpayers not in the top brackets depended on the strength of the tax cut relative to the inflationary impact. A third effect, also induced by inflation, is clearer. Because the "zero-bracket amount," the beginning bracket for taxation, was not changed in nominal dollars, many taxpayers have found it advantageous to begin itemizing their deductions as the nominal value of their expenditures continues to rise throughout this period. Thus, the percentage of itemizers would be expected to increase. Since the price of giving for itemizers before 1986 is less than that faced by nonitemizers, this trend toward itemization implies a lower overall price of giving. Fourth, above-the-line deductions would be expected to have a significant impact on giving by nonitemizers beginning in 1985, the year in which the limit on contributions was lifted. This provision is likely to have its greatest impact among low and middle income taxpayers. Since these taxpayers give a large proportion of their donations to religious organizations, one would expect the above-the-line provision to have its major impact on such institutions.

Table 5 presents simulations based on an econometric model of charitable giving that attempt to show the likely effect of the 1981 tax act, taking together all of the influences discussed above. ${ }^{28}$ The model takes official estimates of income and price growth as a basis for future incomes and the changes to be undertaken in the indexation beginning in 1985. The probable effect of rising nominal incomes in the presence of a fixed nominal zero bracket amount is shown in the third column, which shows the estimated percentage of taxpayers who itemize their deductions over time. This proportion increases from $31 \%$ in 1980 to over $36 \%$ in 1986 . By itself, this effect serves to encourage contributions by increasing the number of taxpayers enjoying the deduction. The fourth and fifth columns give estimates of total contributions by itemizers and nonitemizers. In constant

26. For example, taxpayers subject to the maximum tax on earned income under previous law had prices greater than $\$ .30$ per dollar. See Clotfelter \& Salamon, The Impact of the 1981 Tax Act on Individual Charitable Giving, 35 NAT'L TAX J. 171, 175 (1982), for an explanation.

27. For a discussion of this process, see Clotfelter, Tax Cut Meets Bracket Creep: The Rise and Fall of Marginal Tax Rates 1964-84, 12 PuB. Fin. Q. 131, 132 (1984).

28. One basic model used to estimate the effect of changes in price and income on giving is the constant elasticity form:

$$
G_{1}=G_{0}\left(P_{1} / P_{0}\right)^{b}\left(Y_{1} / Y_{0}\right) a,
$$

where $G$ is contributions, $P$ is price, $Y$ is net income, $O$ refers to actual or beginning values, $l$ refers to the simulated values, and $a$ and $b$ are constant parameters. For a more complete discussion of the simulation methodology, see C. Clotfelter, supra note 1 , at ch. 3 . 
dollars, total giving is estimated to have changed very little between 1980 and 1983 , then to have risen slightly in 1984 and 1985. The largest jump in total contributions is projected to occur in 1986, when the full above-the-line deduction is in force. The final column of the table indicates that contributions by those with the highest incomes will not increase as fast as donations by the group of taxpayers as a whole. The proportion of total contributions given by taxpayers in the top brackets (i.e., taxpayers with incomes over $\$ 50,000$ in 1980 ) is projected to decline from $24 \%$ in 1980 to $18 \%$ in 1986.

TABLE 5

Simulations of Individual Giving, 1981-1986

\begin{tabular}{|c|c|c|c|c|c|c|}
\hline \multirow[t]{2}{*}{ Year } & \multicolumn{2}{|c|}{$\begin{array}{l}\text { Assumed increase } \\
\text { from previous year }\end{array}$} & \multirow[t]{2}{*}{$\begin{array}{l}\text { Percent } \\
\text { itemizing }\end{array}$} & \multicolumn{2}{|c|}{$\begin{array}{c}\text { Total Contributions } \\
\text { (billions) }\end{array}$} & \multirow{2}{*}{$\begin{array}{l}\text { Percent given by } \\
\text { taxpayers with } \\
\text { incomes over } \$ 50,000 \\
\text { in } 1980\end{array}$} \\
\hline & Income & Prices & & $\begin{array}{c}\begin{array}{c}\text { Current } \\
\text { dollars }\end{array} \\
\end{array}$ & $\begin{array}{c}1981 \\
\text { dollars }\end{array}$ & \\
\hline 1980 & - & - & $31.0 \%$ & $\$ 38.7$ & $\$ 42.4$ & $23.8 \%$ \\
\hline 1981 & $11.6 \%$ & $9.4 \%$ & 32.6 & 42.9 & 42.9 & 22.6 \\
\hline 1982 & 4.1 & 6.0 & 33.1 & 44.9 & 42.4 & 21.4 \\
\hline 1983 & 6.7 & 5.2 & 34.0 & 47.2 & 42.2 & 20.3 \\
\hline 1984 & 9.3 & 5.2 & 35.3 & 50.5 & 43.0 & 19.4 \\
\hline 1985 & 9.1 & 4.9 & 35.7 & 54.6 & 44.4 & 18.6 \\
\hline 1986 & 8.8 & 4.6 & 36.2 & 60.5 & 47.0 & 17.9 \\
\hline
\end{tabular}

Although it is still too early to measure the effects of ERTA here, preliminary evidence suggests that some of these effects are indeed being observed. Table 6 gives average contributions by itemizing taxpayers for 1981 and 1982. The major change between these two years, of course, was the drop in marginal tax rates affecting the highest income groups. As the table shows, average contributions at the highest income levels dropped markedly over this period, while contributions at other income levels rose moderately. Because of the large increase in the price of giving at upper income levels, the decline in giving in the top brackets is quite consistent with the economic model of giving.

The implications of these differential impacts by income level are shown in Table 7, which simulates contributions in 1981 and 1986 according to type of organization. Over this period, gifts to religious organizations are projected to increase by $14 \%$ in real dollars. In sharp contrast, contributions to cultural organizations and colleges and universities will drop significantly, by an estimated $17 \%$ and $13 \%$, respectively. Gifts to other educational institutions are also projected to decline. Due to the particular characteristics of the 1981 tax act, therefore, total charitable contributions will rise in real terms over the period 1981 to 1986 . However, virtually all of this growth will occur in the contributions of taxpayers with low and moderate incomes, taxpayers who donate a large proportion of their gifts to religious organizations. Gifts donated by wealthy taxpayers will be encouraged much less than under the 
previous tax law, and this suggests a decline in contributions to organizations supported primarily by upper income individuals.

TABLE 6

Average Contributions by Itemizers, 1981 \& 1982a

\begin{tabular}{lrrr}
\hline \hline Income & \multicolumn{2}{c}{ Average Contributions } & Percent \\
\cline { 2 - 4 } & 1981 & 1982 & Change \\
\hline Under $\$ 5,000$ & $\$ 192$ & 192 & 0 \\
$\$ 5,000-10,000$ & 490 & 516 & +5 \\
$\$ 10,000-15,000$ & 574 & 583 & +2 \\
$\$ 15,000-20,000$ & 595 & 617 & +4 \\
$\$ 20,000-25,000$ & 613 & 646 & +5 \\
$\$ 25,000-30,000$ & 643 & 685 & +7 \\
$\$ 30,000-50,000$ & 885 & 918 & +4 \\
$\$ 50,000-100,000$ & 1,709 & 1,689 & -4 \\
$\$ 100,000-200,000$ & 4,716 & 4,533 & -16 \\
$\$ 200,000-500,000$ & 14,483 & 12,099 & -33 \\
$\$ 500,000-1,000,000$ & 50,125 & 33,834 & -28 \\
$\$ 1,000,000$ or more & 204,499 & 146,530 & 4 \\
\hline
\end{tabular}

aEpstein, Preliminary Income and Tax Statistics for 1982 Individual Income Tax Returns, 3 STATS. Income Bull., Winter 1983-84, at 11, 19, Table 1; U.S. Internal Revenue Service, Statistics of Income1981: Individual Income Tax Returns 53-54, Table 2.1.

\section{TABLE 7}

Projected Contributions by Type of Organization, $1981 \& 1986$

\begin{tabular}{lrrr}
\hline \hline Organization Type & \multicolumn{2}{c}{$\begin{array}{c}\text { Contributions } \\
\text { (billions, 1981 dollars) }\end{array}$} & $\begin{array}{c}\text { Percent } \\
\text { Change }\end{array}$ \\
\cline { 2 - 3 } & \multicolumn{1}{c}{1981} & 1986 & $+14 \%$ \\
\hline Religious & $\$ 30.60$ & $\$ 34.95$ & -13 \\
Colleges and universities & 2.10 & 1.83 & -9 \\
Other education & 0.68 & .62 & +2 \\
Combined appeals & 2.53 & 2.58 & +2 \\
Medical & 2.49 & 2.54 & -17 \\
Cultural & 0.65 & 0.54 & +1 \\
Other & $\mathbf{3 . 6 8}$ & $\mathbf{3 . 7 3}$ & $+10 \%$ \\
Total & $\$ 42.91$ & $\$ 47.00$ & \\
\hline
\end{tabular}




\section{IV}

\section{ECONOMIC RECOVERY TAX ACT OF 1981: ESTATES AND CORPORATIONS}

Several provisions of ERTA are likely to influence giving by estates and corporations. ERTA changed the estate tax by significantly increasing the unified credit (a tax credit applying to gift and estate taxes together), ${ }^{29}$ reducing the top tax bracket rate from $70 \%$ to $50 \%, 30$ and introducing an unlimited marital deduction. ${ }^{31}$ A major effect of the increase in the unified credit has been to reduce the number of estates subject to the tax at all. In constant dollars, the minimum size estate subject to the tax is projected to increase by $150 \%$ between 1981 and $1987 . .^{32}$ For the largest estates, the reduction in tax rate has the effect of increasing the price of making charitable bequests, as compared to noncharitable bequests, in the same way that the personal tax rate cut increased the price of giving by living individuals. The effects of the increased credit and the cut in rates at the top are similar: they both serve to increase the relative price of charitable bequests for many estates, especially the largest estates. The impact of the unlimited marital deduction is less clear, since this provision allows postponement, but not cancellation, of tax liabilities. ${ }^{33}$

Econometric studies of bequest giving suggest that the estate tax influences gifts through its effect on the net estate and, similar to the case of living individuals, its effect on the relative price of charitable bequests. ${ }^{34}$ As in the case of individuals, price has a measured negative effect on giving, although the evidence in this area is thinner and more variable than for individual giving. Using parameters estimated from recent data, ${ }^{35}$ the effect of the 1981 tax act on bequest giving has been simulated. Total charitable bequests are likely to fall by at least one-third, from $\$ 2.3$ billion to $\$ 1.5$ billion in 1976 as a result of ERTA. Although such a projection is subject to considerable uncertainty, it illustrates the potential impact of reduced marginal tax rates as applied to the largest estates.

The major change in the corporate tax contained in the 1981 tax act was a significant liberalization of depreciation allowances. ${ }^{36}$ Also relevant to charitable contributions was an increase in the maximum deduction from $5 \%$

29. I.R.C. $\$ 2010$ (a) (Lawyers Co-op. Supp. 1985).

30. Id. $\$ 2001(\mathrm{c})$.

31. Id. \& 2056(a).

32. See C. Clotfelter, supra note 1 , at ch. 6.

33. In addition, the law provides for a deduction for the charitable portion of a class of splitinterest charitable remainder trusts, thus removing any incentive to make bequests to a surviving spouse rather than leave a charitable bequest in such a trust. See Staff of Jr. Comm'n on Tax'N, 97th Cong., 2d Sess., General Explanation of the Economic Recovery Tax Act of 1981, at 238 (Comm. Print. 1981).

34. See C. Clotfelter, supra note 1 , at ch. 6 , for a discussion of this research.

35. The data used for the simulation were from the 1976 Estate Tax File. See C. Clotfelter, supra note 1, at ch. 6.

36. E.g., I.R.C. \& 168(a) (Lawyers Co-op. Supp. 1985) (ACRS property); id. \& 179 (small business). 
to $10 \%$ of net income. ${ }^{37}$ Since few corporations were at the previous limit, it seems likely that the higher limit will have little effect, except in industries in which the new depreciation allowances will reduce net incomes drastically. Although econometric studies do indicate that the corporate tax exerts both an income and price effect on corporate giving, ${ }^{38}$ it is unlikely that the 1981 tax changes will have a significant enough influence on either price or aftertax income to cause corporate giving to be affected greatly.

\section{V}

\section{“Flat-Rate" Income Taxes and Other Reforms}

Spurred by the "supply-side" arguments for lower marginal tax rates, the notion of a "flat-rate" income tax captured a central place in debates over the tax structure during the first term of the Reagan Administration. These tax schemes generally shared two features: lower tax rates (if not literally flat tax schedules) and a broader income tax base. The broader base would have the dual virtues of providing a simplified tax structure, and of allowing comparable revenues to be raised using lower rates. Some proposals sought to eliminate all deductions, ${ }^{39}$ including contributions, while others provided for the continuation of popular deductions. ${ }^{40}$

Whether or not the rate structure was "flat" or progressive, any broadbased income tax would affect individual giving as a result of its impact on net incomes and the price of making contributions. Many of the proposed tax schemes imply a redistribution of the tax burden from upper incomes to lower incomes. Apart from other effects, this would tend to benefit charities favored by the rich, at the expense of those supported by low and middle income taxpayers.

The more important effect of a broad-based tax, however, would be manifested in the price of giving. If the charitable deduction were eliminated, the subsidy for all taxpayers previously enjoying a deduction would disappear. As noted above, it has been estimated that the elimination of the charitable deduction would cause contributions to drop by one quarter. ${ }^{41}$ Even with a deduction, however, a broad-based tax could cause giving to drop significantly, due to the rise in the price of giving resulting from a sizable cut in marginal tax rates.

Provisions of various tax proposals are outlined in Table 8. The first two columns of the table indicate the maximum tax rate and the deduction

37. Id. \& 170(b)(2) (Lawyers Co-op. 1974 \& Supp. 1985).

38. See C. Clotfelter, supra note 1 , at ch. 5 .

39. E.g., H.R. 542, 98th Cong., 1 st Sess., 129 Cong. Rec. H93 (daily ed. Jan. 6, 1983) (Crane); S. 557, 98th Cong., 1 st Sess., 129 Conc. REc. S1507 (daily ed. Feb. 23, 1983) (Hall-Rubushka, DeConcini).

40. E.g., H.R. 3271, 98th Cong., lst Sess., 129 Conc. Rec. H3846 (daily ed. June 9, 1983 ); S. 1421, 98th Cong., Ist Sess., 129 Conc. Rec. S7924 (daily ed. June 8, 1983) (Bradley-Gephardt); H.R. 5533, 98th Cong., 2d Sess., 130 Cong. Rec. H31 28 (daily ed. Apr. 26, 1984); S. 2600, 98th Cong., 2d Sess., 130 Cong. Rec. S4950 (daily ed. Apr. 26, 1984) (Kemp-Kasten).

41. See supra text accompanying note 15 . 
provision for contributions for each tax scheme listed. Based on econometric models of charitable giving, a computer program was written to embody the provisions of these tax proposals and to produce estimates of giving under each regime. ${ }^{42}$ The last two columns of the table show the estimated change in giving under alternative tax plans from giving under current law. 43 One model assumes that price and income elasticities are constant while the other assumes these elasticities vary by income. ${ }^{44}$ Since each estimate is subject to statistical and other errors, all of the estimates should be taken as merely approximating the likely effects.

Of the generic flat-rate taxes, one on adjusted gross income (AGI) has the broadest base and therefore can raise a given amount of revenue with a lower tax rate $(11.8 \%)$ than one on taxable income. Because gross income is the tax base, no deductions are allowed, and the net cost of contributing a dollar is a full dollar. An alternative is to calculate tax as a flat rate $(19.5 \%)$ of currently defined taxable income. Itemizers would continue to receive an incentive, but the rate of subsidy would differ from the rate under current law. For taxpayers currently facing marginal rates above $19.5 \%$, the net price of giving a dollar would rise.

In addition to the flat-tax proposals, Table 8 shows simulated individual giving under more than a dozen tax reform bills introduced in the 98th Congress, as well as the 1984 tax proposal of the Treasury Department. ${ }^{45}$ The specific proposals put forward in Congress and by the Treasury Department differ markedly in their breadth of income coverage, exemption levels, deductions, and tax rates. The DeConcini and Roth bills are variants of an expenditure tax as distinguished from an income tax. The Treasury Department's tax plan of November 1984 is a broad-based income tax. The maximum marginal tax rates vary between $10 \%$ and $50 \%$.

Charitable contributions as presently defined would be deductible in most bills, either by itemizers or by all taxpayers, while only religious contributions would be deductible under the Hansen bill. The Hatfield bill replaces the deduction with a credit, subject to a $1 \%$ of AGI floor. The Treasury proposal eliminates the deduction for nonitemizers, imposes a $2 \%$ of AGI floor for the itemized charitable deduction, and ends the favorable treatment of gifts of appreciated assets.

42. For a description of the methodology used in the simulation, see C. ClotFelter, supra note 1 , at ch. 3.

43. The current law has tax rates up to $50 \%$ and provides a special charitable deduction for nonitemizers amounting to $50 \%$ of gifts without limit. In 1986 this special deduction is scheduled to be $100 \%$ of contributions. I.R.C. 8170 (i)(2) (Lawyers Co-op. Supp. 1985).

44. For a discussion of these models, see Clotfelter, Tax Reform and Charitable Giving in 1985, 26 TAX Notes 477, 480-81 (1985).

45. For a description of the most important provisions of these tax plans, see id. at $486-87$. 
TABLE 8

Present law and Selected Tax Proposals: Maximum Tax Rate AND Provisions for Contributions

\begin{tabular}{|c|c|c|c|c|}
\hline \multirow[t]{2}{*}{ Description } & \multirow[t]{2}{*}{$\begin{array}{l}\text { Maximum } \\
\text { tax rate }(\%)\end{array}$} & \multirow[t]{2}{*}{$\begin{array}{l}\text { Provision for } \\
\text { contributions }\end{array}$} & \multicolumn{2}{|c|}{$\begin{array}{l}\text { Predicted giving: Percent } \\
\text { change from } 1985\end{array}$} \\
\hline & & & $\begin{array}{c}\text { Constant } \\
\text { elasticity } \\
\text { model } \\
\end{array}$ & $\begin{array}{c}\text { Variable } \\
\text { elasticity } \\
\text { model }\end{array}$ \\
\hline \multicolumn{5}{|l|}{ Current law } \\
\hline 1985 & 50 & $\begin{array}{l}\text { Itemized deduction; } \\
50 \% \text { deduction for } \\
\text { nonitemizers }\end{array}$ & - & - \\
\hline \multicolumn{5}{|l|}{ Generic flat-rate taxes } \\
\hline Flat rate on $\mathrm{AGI}$ & 11.8 & None & -32 & -27 \\
\hline Flat rate on taxable income & 19.5 & Itemized deduction & -17 & -15 \\
\hline \multicolumn{5}{|l|}{ Tax reform proposals-98th Congress } \\
\hline $\begin{array}{l}\text { Bradley-Gephardt (H.R. 3271; S. } \\
\text { 1421) }\end{array}$ & 30 & Deduction (at $14 \%$ ) & -23 & -23 \\
\hline DeConcini (S. 557) (Hall-Rubushka) & 19 & None & -94 & -30 \\
\hline Kemp-Kasten (H.R. 5533; S. 2600) & 25 & Deduction* & -13 & -15 \\
\hline Quayle (S. 1040) & $\mathbf{3 0}$ & Deduction $\dagger$ & -19 & -22 \\
\hline Hatfield (S. 2158) & $\mathbf{3 0}$ & $\begin{array}{l}20 \% \text { credit over } 1 \% \\
\text { AGI }\end{array}$ & -9 & -13 \\
\hline Crane (H.R. 542) & 10 & None & -32 & -26 \\
\hline Mitchell (S. 1767) & 36 & $\begin{array}{l}\text { Itemized deduction } \\
\text { (at } 12 \% \text { ) }\end{array}$ & -24 & -22 \\
\hline Hansen (H.R. 170) & 15 & $\begin{array}{l}\text { Deduction for } \\
\text { religious gifts* }\end{array}$ & -23 & -21 \\
\hline Heftel (H.R. 5841) & 50 & $\begin{array}{l}\text { Itemized deduction to } \\
5 \% \text { AGI }\end{array}$ & -15 & -13 \\
\hline Stark (H.R. 6308) & 50 & $\begin{array}{l}\text { Deduction reduced } \\
\text { by } 10 \%\end{array}$ & $-8 * *$ & $\cdot$ \\
\hline Dreier (H.R. 1770) & 14 & None & -32 & -27 \\
\hline Roth (S. 3042) & 45 & Deduction* & -7 & -8 \\
\hline Treasury I proposal & 35 & $\begin{array}{l}\text { Itemized deduction } \\
\text { over } 2 \% \text { AGI; } \\
\text { constructive } \\
\text { realization }\end{array}$ & -20 & -19 \\
\hline \multicolumn{5}{|l|}{ Modifications of current law } \\
\hline $20 \%$ charitable credit & 50 & $20 \%$ tax credit & -11 & -13 \\
\hline Full deduction for nonitemizers & 50 & Deductiont & +6 & +3 \\
\hline No charitable deduction & 50 & None & -32 & -26 \\
\hline Present law with $10 \%$ surtax & 55 & See 1985 law & $+4 * *$ & - \\
\hline Present law with VAT & 50 & See 1985 law & $-2 * *$ & - \\
\hline
\end{tabular}

"Deduction for nonitemizers assumed $50 \%$ in 1985.

†Assumed to apply fully to nonitemizers.

* Intended explicitly to increase revenues. No revenue adjustment assumed.

Finally, the table presents the change in giving effected by several modifications of 1985 law, including a $20 \%$ credit in place of the charitable deduction, a full deduction for nonitemizers (in place of the $50 \%$ deduction), the elimination of the deduction, a general surtax, and a supplementary valueadded tax.

The estimates in Table 8 clearly suggest that tax reform proposals will have the effect of reducing charitable giving by individuals. Although the magnitudes differ-with the largest declines in proposals that drop the 
deduction altogether-all of the tax reform proposals imply declines. The smallest declines occur in proposals that retain the current deduction and maintain relatively high marginal tax rates. The only proposal associated with an increase in giving is the current law with a surtax tacked on; such a law would have higher rather than lower tax rates and consequently lower prices of charitable giving.

\section{Conclusion}

At the time of this writing, it is obviously too early to know the final shape of taxes in the "Reagan era." However, the legislation of the first term and the proposals of 1983 and after highlight two important effects. The first and more important is tax rate reduction. Reductions in marginal tax rates, embodied in ERTA and a host of proposed tax changes, have the effect of increasing the net cost of giving a dollar to charity. As long as the deduction remains the chief tax incentive Congress can give, its cuts of the tax rate will tend to weaken that tax incentive. Increases in after-tax income may, at some income levels, exert a positive effect on giving, but in general the adverse price effects will tend to dominate these income effects. These adverse price effects are most evident in the income tax, but they are also present in the rate cuts in the estate tax.

A second effect of Reagan era tax legislation is its impact on the incentive of nonitemizing taxpayers to make contributions. From the time of the introduction of the standard deduction in 1944 until 1981, the income tax had offered nonitemizers no reduction in the price of giving. Consequently, the phased-in deduction for nonitemizers in ERTA represents a change in tax policy of great importance. It is by no means clear, however, whether this provision will be retained in the tax law. Besides the existence of the itemized charitable deduction itself, no other tax provision except the rate structure has so much potential impact on the level of charitable giving as the deduction for nonitemizers. Only if a tax credit is adopted in place of the charitable deduction for both itemizers and nonitemizers will the deductibility of gifts and rate of taxation lose their central importance in determining the level of philanthropic giving in this country. As long as the deduction is the basic form of incentive for giving, the trends toward tax rate reduction and limitation of the deduction will tend to discourage charitable giving. 